\title{
Food Security and Food Waste
}

\author{
Jonathan Cloke
}

\begin{abstract}
The chapter is aimed at providing a practical framework for a reconsideration of the themes behind the term "food security." The analysis illustrates that since the term gained popular currency in the mid-1990s it has been restricted in focus to a few, narrow angles of research revolving around individual citizens, households, and the nation-state without consideration of global food production systems, the socio-environment that dominates food production globally. There is an urgent need for a relational understanding of food production and consumption in research on food security that understands how and why food is consumed; a biopolitical take based on understanding global mass consumption and the drivers of food capitalism, over- and -under-consumption.
\end{abstract}

Keywords Waste - Vastogenic - Food regime - Corporate - Security • Production - Consumption - Obesity

In 2013, I wrote an article on food security (Cloke 2013) analysing the difficulties involved in defining that concept. The article looked at the evolution of the term, not by taking it on its own terms, ${ }^{1}$ but by examining what it could mean in a world dominated by corporate food production and distribution networks that waste a substantial portion of the food produced globally and profit from that waste, systems referred to in the literature as global food production regimes. It seemed a logical absurdity that in a world already producing enough food to feed the global population (OECD 2009), so much academic, political and corporate effort has gone into constructing forms of food security that effectively ignore the

\footnotetext{
${ }^{1}$ See here for a reprise of the difficulties involved according to the FAO-TRADE REFORMS AND FOOD SECURITY: Conceptualizing the Linkages, Chapter "Globalisation and Malnutrition: Geographical Perspectives on its Paradoxes": Food security: concepts and measurement, http://www.fao.org/docrep/005/y4671e/y4671e06.htm\#fn21.
}

J. Cloke $(\bowtie)$

Department of Geography, Loughborough University, Leicestershire LE11 3TU, UK

e-mail: J.M.P.Cloke@lboro.ac.uk

(C) The Author(s) 2016

P. Jackson et al. (eds.), Eating, Drinking: Surviving,

SpringerBriefs in Global Understanding, DOI 10.1007/978-3-319-42468-2_11 
overwhelming importance of what I referred to as vastogenic (waste-creating, waste-profiting) systems.

The article went on to cover research pointing out that over the 70 years since the end of World War II, a determinable set of political and social initiatives have shaped global corporate food regimes in Europe, the US, and elsewhere into social systems that sit outside the control of all but a few of the most powerful nation-states - social food mobilizing systems that profit from their vastogenic components. Food security (however defined) is increasingly dependent on the internal structures and processes of a diminishing number of corporate food wholesalers and retailers, plus those controlling the production factor chains of global agriculture such as seeds, fertilizers, and pesticides. Critically, food waste is not just some regrettable side effect of these systems that will be taken care of by technical, regulatory, and organizational fixing; it has become a core component of the way these systems have developed-waste speeds up the profitable through-flow of food and is an increasing part of the profit mechanism.

To combat the official and institutional systemic myopia, a shift of global geographical vision is required, away from the productivity and population biases that comprise the current food security discourse, and towards the spatiality and biopolitical aspects of these vastogenic systems (including their social, political and economic embeddedness), what Misselhorn et al. (2012) describe as a food systems approach. Global food production systems for instance do not just passively distribute food from zones of mass food production to an increasingly spatially diverse and growing range of zones of mass food consumption, they are dynamic systems with the agency, power and profit-motive to ceaselessly create new appetites and diets, particularly now amongst the fast-growing consumer classes of South and East Asia. Essentially, the profitability of these systems is built on the gradient between higher priced means of delivery in higher income zones and lower cost methods of production in low-income areas-areas where food insecurity is a substantial issue. That gradient can be made steeper by a contractual dominance over small food producers acting to cheapen production factor costs, and through a range of measures to speed up food waste (and thus turnover) once it exits the doors of the system.

It is worth reviewing some of the figures to illustrate the size of (and increase in) food waste. The EU points out that up to $50 \%$ of the edible food passing through them is wasted by European households, supermarkets, and restaurants each year; a quantity which it is estimated will grow by $40 \%$ by 2020 under current circumstances (European Parliament 2012). In the US $40 \%$ of all food production is wasted, $25 \%$ of which is thrown away by Americans when they get home (Buzby and Hyman 2012) - the quantity being wasted in the US has also increased by about $50 \%$ since the 1970 s from $30 \%$ of the total to $40 \%$ (Hall et al. 2009). Globally, the figure for overall waste is about one third of all food (Hall et al. 2009; FAO 2011), but food waste is overwhelmingly dominated by consumers in zones of mass food consumption: "Consumers in rich countries waste almost as much food, 222 million tonnes, as the entire net food production of sub-Saharan Africa (FAO 2011: 5)." In some food categories (seafood, fresh vegetables), the systemic 
conduits over-supplying the US, Canada, Australia, and New Zealand already waste more than half of the food produced designated to feed the people in these countries (NDRC 2012).

Food waste systems also act as epicentres emitting global ripples of other, different kinds of waste; food waste in the US wastes $25 \%$ of all fresh water consumption and $4 \%$ of total US oil consumption, for instance, and food rotting in landfills in the US constitutes some $25 \%$ of US methane emissions (Hall et al. 2009). In the UK it is estimated that avoidable food waste in 2010 led to emissions of $\mathrm{CO} 2$ equivalent to a fifth of all the cars on roads in the UK, and the water used in that waste equalled $5 \%$ of UK drinking water needs (WRAP 2011). Food production systems are a major source of resource waste in a world of finite resources, and the actions and processes involved in operationalizing that waste are themselves important drivers of anthropogenic global warming, whether from the waste of fuel oil used to transport food straight into the landfills and spoil tips of the EU and North America, or from the millions of tons of greenhouse gases created by that waste. These drivers of waste are accelerating, moreover; as per-capita consumption of meat doubled in China between 1990 and 2005 (Fritschel 2008) for instance, the complexity of effects in terms of demand for feedgrain, resource waste, competition with biofuels, land availability, and environmental degradation have been immense and global in extent.

Despite these biopolitical, overconsumption, and systemic drivers of food insecurity and shortage, food waste is inexplicably left out of the official discourses on supplying food to a growing global population, in much the same way that systemic, consumption-derived food waste is left out of the official discussions on food security. In addition, just as the official take on food security remains firmly fixed at the nation-state and household level with no analysis of corporate food production systems allowed to muddy the waters, so the official take on global food supply is unrelentingly productivist; feeding a growing global population and those currently malnourished and starving is only ever an issue of increased investment and production. In this take:

\footnotetext{
Food security for all could be within reach. The conditions under which this can be achieved are strong economic growth, global expansion of food supplies by about 70 percent, relatively high production growth in many developing countries achievable through growing capital stock, higher productivity and global trade helping the low income food deficit countries to close their import gaps for cereals and other food products at affordable prices. (FAO 2009: 14)
}

In this Panglossian vision, no mention is made of how much of the $70 \%$ increase in production will be wasted, even though under current trends this would be more than half of that increase. The FAO does admit that "the whole structure of market chains is likely to continue its dynamic change towards a further concentration of supermarket chains" (2009: 6), but for the main part where corporations are mentioned in institutional and official literature it is as part of the solution, not the problem. Corporate agribusiness particularly is written into the literature on food security as a white knight, a blend of biotechnological and commercial 
biopower acting as a panacea to the threatening Malthusian 'dystopia' (Duffield 2009) of immanent food shortages. GMOs and biotechnology are increasingly viewed as inevitable and vital in the productivist vision through a range of political and institutional optics, not least through the agency of those corporations themselves.

Meanwhile, in the rapidly increasing zones of mass food consumption, for consumers a plethora of food management technologies, ranging from the technical such as cheaper and more efficient refrigerators and freezers to the legal such as hygiene regulations and sell-by/best-before dates persuade households to store more (and therefore waste more) food. These technologies are reinforced by sustained advertising campaigns dedicated to behavioral change through which consumers are sold images of dietary sophistication at the same time as being inundated with persuasive images to just buy (and hence waste) more food. The US obesity epidemic for instance results at least as much "from a 'push effect' of increased food availability and marketing with Americans being unable to match their food intake with the increased supply of cheap, readily available food (Hall et al. 2009: 2)" as it does from demand derived from consumers themselves.

Within global food production systems, waste derives from a similarly wide range of profit-related factors, beginning with sales agreements with small farmers driving lower prices in buyer-dominated markets for foodstuffs which must meet demanding quality standards for shape and appearance (FAO 2011, Op. cit.) — such contracts often stipulate quantity guarantees and the ability to change orders at the last minute. Once inside food production systems which must take the financial hit from losses and waste, losses drop dramatically; whereas average production loss for all types of food is $7.8 \%$ globally, post-harvest, handling and storage losses are only $1.55 \%$, processing and packaging losses $4.1 \%$ and retail losses average $5.55 \%$ (NDRC 2012, Op. cit.) — it is at the retail/consumer interface that the truly dramatic wastage takes place.

A vast array of mechanisms maximizes food waste in shops, restaurants, and stores and therefore through-flow in retail/consumption spaces-overstocked product displays; learned behavior concerning cosmetic perfection; pack sizes that are too large; the availability of fresh, ready food until store closing; damaged goods, outdated promotional products, and unpopular items; bulk discounts; merchandising encouraging impulse buys and high-volume promotions (buy one, get one free) all persuade consumers to purchase food they are unlikely to consume (NDRC 2012, Op. cit.): "Other drivers of waste in food service include large portions, inflexibility of chain-store management, and pressure to maintain enough food supply to offer extensive menu choices at all times" (Kantor et al. 1997: 2-12).

Meanwhile, official bodies continue to frame food waste as an ethical, moral, and social problem (European Parliament 2012, Op. cit.) and to mount campaigns such as "European year against food waste" and "Love Food Hate Waste" to mobilize political will and get food retailers to sign up to voluntary codes of practice. The global reality, however, is that an increasing percentage of a rapidly increasing global food supply is being wasted (along with the resources it takes to produce, 
transport, and sell that food), in a major part because the way in which the world's corporatized global food regimes have developed makes it profitable to do so:

The reality as a regional grocery manager is, if you see a store that has really low waste in its perishables, you are worried. If a store has low waste numbers it can be a sign that they aren't fully in stock and that the customer experience is suffering. Industry executives and managers view appropriate waste as a sign that a store is meeting quality control and full-shelf standards, meaning that blemished items are removed and shelves are fully stocked (Alvarez and Johnson 2011; quoted in NDRC 2012).

There is a virtual absence of research and analysis into corporate profit as the driving engine for food and resource waste, however, as well as the role it plays in global climate change. In the US, the most comprehensive analysis on US food waste was done by the USDA in 1997 and little has been done since; the situation in other developed market economies is little better and overall food waste continues to be treated as a curious, sad, but in the end side issue, rather than the mainstream phenomenon of consumer capitalism that it is. Above all, the corporate food regime as a profiteer from waste is the Macavity of research subjects; when the time comes to do a realistic analysis of the driving forces behind food waste, it isn't there ....

\section{References}

Alvarez, J., \& Johnson, R. (2011, November). Doug Rauch: Solving the American Food Paradox. Harvard Business Review, N9-012-022.

Buzby, J., \& Hyman, J. (2012). Total and per capita value of food loss in the United States. Food Policy, 37, 561-570.

Cloke, J. (2013). Empires of waste and the food security meme. Geography Compass, 7(9), $622-636$.

Duffield, M. (2009) Liberal interventionism and the fragile state: Linked by design? In M. Duffield \& V. Hewitt (Eds.) Empire, development and colonialism: The past in the present (pp. 116-129). Suffolk: James Currey.

European Parliament. (2012). Parliament calls for urgent measures to halve food wastage in the $E U$. Press Release Reference No: 20120118IPR35648.

FAO. (2009). How to feed the world in 2050. Paper from the high level expert forum-How to feed the world in 2050, Rome June 2009. Available at http://www.fao.org/fileadmin/templates/ wsfs/docs/expert_paper/How_to_Feed_the_World_in_2050.pdf. Accessed February 5, 2015.

FAO. (2011). Global food losses and food waste - Extent, causes and prevention. Rome: FAO.

Fritschel, H. (2008). The price of food: Ingredients of a global crisis, Open democracy. Available at http://www.opendemocracy.net/article/globalisation/. Accessed March 28, 2011.

Hall, K., Guo, J., Dore, M., \& Chow, C. (2009). The progressive increase of food waste in America and its environmental impact. PLOS ONE, 4(11), e7940.

Kantor, L., Lipton, K., Manchester, A., \& Oliveira, V. (1997). Estimating and addressing America's food losses. USDA Food Review (pp. 2-12), January-April 1997.

Misselhorn, A., Aggarwal, P., Ericksen, P., Gregory, P., Horn-Phathanothai, L., Ingram, J. and Wiebe, K. (2012). A vision for attaining food security. Current opinion in environmental sustainability, 4(1), February 2012, 7-17. 
NDRC. (2012). Wasted: How America is losing up to 40 percent of its food from farm to fork to landfill. NDRC Issue Paper, August 2012 IP:12-06-B.

OECD. (2009). The bioeconomy to 2030: designing a policy agenda. OECD International Futures

Project. Available at http://www.oecd.org/futures/bioeconomy/2030, Accessed April 29, 2011.

WRAP. (2011). New estimates for household food and drink waste in the UK. Final Report version 1.1 .

Open Access This chapter is distributed under the terms of the Creative Commons Attribution 4.0 International License (http://creativecommons.org/licenses/by/4.0/), which permits use, duplication, adaptation, distribution and reproduction in any medium or format, as long as you give appropriate credit to the original author(s) and the source, provide a link to the Creative Commons license and any changes made are indicated.

The images or other third party material in this chapter are included in the work's Creative Commons license, unless indicated otherwise in the credit line; if such material is not included in the work's Creative Commons license and the respective action is not permitted by statutory regulation, users will need to obtain permission from the license holder to duplicate, adapt or reproduce the material.

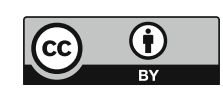




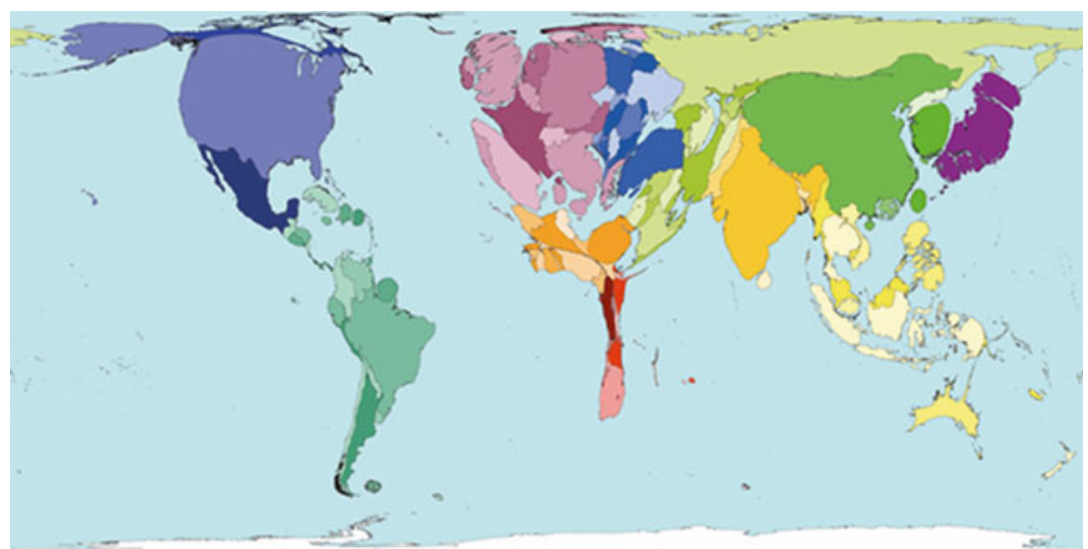

Waste collected. This map shows waste collected from homes, schools and businesses. The most waste is produced in China, where the biggest population lives. The most waste produced per person is generated in the Russian Federation. Territory size shows the proportion of all municipal waste generated worldwide that is generated there. Source www.worldmapper.org. Published with kind permission of (C) Copyright Benjamin D. Hennig (Worldmapper Project)

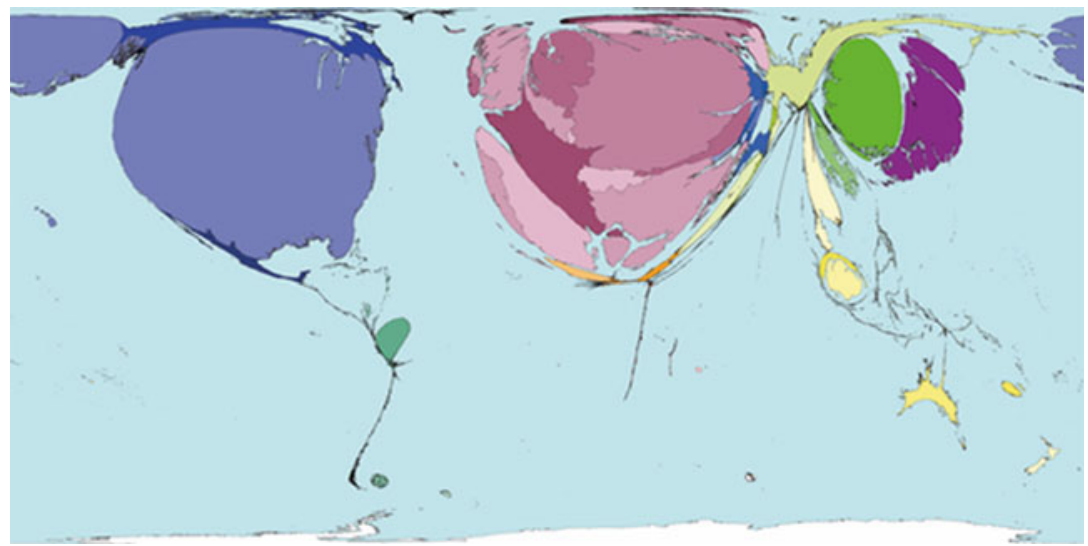

Waste recycled. Worldwide, in 2002, $6.6 \%$ of municipal waste produced was recycled. Recycling means reusing 'waste' in the production process. Those territories where much waste is recycled are mainly in North America, Western Europe, but also include Japan and the Republic of Korea. Territory size shows the proportion of all municipal waste that is recycled, that is recycled there. Source www.worldmapper.org. Published with kind permission of (C) Copyright Benjamin D. Hennig (Worldmapper Project) 